\title{
Arguments for empowering Southern Carpathians communities in sustainable forestry management based on a perception approach in selected areas
}

\author{
Elena MATEI ${ }^{a}$, Daniel LUCHEȘ ${ }^{b}$, Gabriela MANEA ${ }^{a}$ IUliana VIJULIE ${ }^{a}$, \\ Mihaela PREDA ${ }^{a}$, Octavian COCOŞa1 \\ aUniversity Bucharest, Faculty Faculty of Geography, University of Bucharest, N. Bălcescu Av., No.1, \\ 010041,Bucharest, Romania \\ ${ }^{b}$ Timişoara West University, Faculty of Sociology and Psychology, Pârvan Vasile Av., No. 4, 300223, \\ Romania
}

\begin{abstract}
In Romania, the changes of the land fund occurring over the last decades due to land restitutions haveled to some difficulties in the management of the marked forests and to excessive harvesting in all geographical areas, but especially in the Carpathian Mountains. Although these topics have been intensely publicized, the general reaction of the population and, implicitly, of the local communities, towards these signals has been week and isolated. Consequently, the study aims at examining the perception of local Carpathian communities, as actors involved in sustainable development, which are required to assume an active participation in the sustainable management (SFM) of the forests lying in the vicinity of residential areas. In order to accomplish this, an interview was applied in eight pilot areas from the Southern Carpathians. The results reveal that, regardless of education level, the respondents have a deep environmental knowledge about forest ecosystems, a perception in which the interest goes primarily to forest maintenance and only then to economic harvesting. The perception regarding the forests' condition, the activity of the administrators and the specific legislation is predominantly negative. In ord er to overcome the dysfunctions the members of local communities support legislation improvement, the increase of environmental awareness by education, being willing to get involved in a wide range of activities to enhance SFM. The study may be a useful tool for policy makers and for improving the activities by involving local population, which is the main target of SFM.
\end{abstract}

Key words: forest knowledge, involvment, local communities, perception, SFM

\section{Introduction}

The extremely complex issue of forest dynamics due to anthropogenic and natural causes, the increasing reconsideration of its ecosystemic, economic and social services in the context of climate change have led in recent decades to an intensification of scientific research (Badea et al., 2012), on the one hand, and to a correlation of management policies in consensus with the paradigm of sustainable development in the EU and many other countries of the world, on the other hand. Romania, as an EU member state, must align with these trends, but changes in forest ownership after 1990 have led to the management dysfunctions that still pose major problems, especially in the more vulnerable Carpathian area, through forest expansion and land fragmentation. Besides, as in other states of the former communist bloc, which have shifted from a centralized to a market economy, this mountain space is affected by labor migration to other

\footnotetext{
${ }^{1}$ Corresponding author Octavian COCOŞ; E-mail: octaviancocos@yahoo.com Received: November 2020, Published: December 2020
} 
European countries, and consequently many lands have been abandoned by landowners (Munteanu et al., 2014). In the mountain area, the forest either expanded naturally (Munteanu et al., 2014; Matei et al., 2016), or shrank under the attack of some insects, or because of wildfires and uncontrolled felling, which is prevailing (Kuemmerle et al., 2008; Knorn et al., 2012; Vijulie et al., 2018). There are cases in which as soon as the forest has been given back to its former owner, this immediately started to cut it down, especially in the '90s, when wood harvesting by "saw mills" in the Carpathian areas intensified (Mantescu \& Vasile, 2009).

Under the circumstances, the forest area in Romania, although there is not enough relevant information given the conversions between categories of woods (Griffiths et al., 2014), has fluctuated in the last decades by $\pm 1-2 \%$, being $26.7 \%$ in 1990, 27.6\% in 2019 (INS, 2020). About half $(48.9 \%, 2015)$ of the forest fund is owned by the state and administered by ROMSILVA Company. The other half, privately owned, following the application of Law no. 18/1991 (surface restitution up to 1 ha), Law 1 of 2000 (restitution up to 10 ha) and Law no. 247/2005, ("restitutio in integrum") (Abrudan et al., 2009), is divided between various owners. It is administered by different entities, but sometimes there is no administration at all. Following these restitution efforts, there are still numerous conflicts related to property, a fact reflected by the structure that does not mirror the property structure that was before the nationalization of the communist regime (Mantescu \& Vasile, 2009), and the owners exploitation/use rights are still at a low level compared to Western European states (Nichiforel et al., 2020).

In Romania, forests are considered a national asset (art. 3.1, Law 46, 2008), over which the owners do not have an absolute right. Consequently, they but must obey the laws and keep them as open spaces where circulation is free, which makes them somehow available for people and communities with various behaviors. Moreover, Romania, as an EU state, is in the process of implementing the European policy on Sustainable Forest Management (SFM) established in 1993 and continuously improved and monitored on the six key criteria (maintaining the role of the forest to global carbon cycles; ecosystems 'health and vitality, productivefunctions, enhancement of biological diversity, protective functions, socioeconomic functions (Forest Europe, 2020). SFM, as well as the directions provided by the European Convention of Land (ECL) (2000), regarding conservation and environmental protection, add value through social and cultural reconsiderations (Canadas \& Novalis, 2014) support a multidirectional effort in which the public is seen as a key player in the management of European areas (ECL, 2000).

Hence, the present study aimed to investigate the local community perception, in vederea identificarii potentialului lor de implicare in gestionarea durabila fondului local forestier. Hence, the present study aimed at investigating the local community perception, in order to identify its potential for involvement in the sustainable management of the local forest fund. This article focuses on eight local mountain communities in Romania having forest perimeters, which are under their ownership or not.

This study was based on correlative analyses among various variables, such as the level of knowledge about the significance of the forest/forest definition (FD), its benefits (FB), the risks of excessive forest exploitation (ER) and demographic characteristics. Emphasis was put on the educational level, ownership status, and the nature of the regional framework, more or less protected, in order to find arguments regarding the involvement of local communities in SFM.

As far as the environmental forest knowledge is concerned, the study takes into account relevant aspects of the international literature regarding culture, education, knowledge, and attitude. Thus, Ringov and Zollo (2007) stated that culture plays a decisive role in human action 
on the environment. The culture associated with environmental education, thelatter being widely considered a tool for sustainable management produces by synergy, within certain limits, positive pro-environmental attitudes (Chwialkowska et al., 2020). Sustainable forest management, as an issue that must strike a balance between environmental, economic and social aspects, implies a correct institutional approach, from the actual management to education, which should form behaviors based on strong beliefs about the advantages of a long-term exploitation in comparison with an immediate economic harvesting (Barraza, 2001). The knowledge of the population, generated by education or by keeping the traditions regarding forest resources (Parrotta et al., 2016), is often transposed into a perception that generates attitudes, and, implicitly, behaviors, which decisively influence the development of environmental ethics. In this respect, the introduction in the educational system of the knowledge regarding the biological value of forests, leads to a positive change in the perception of young people regarding the importance of sustainable management or preservation (Barraza \& Pineda, 2003). In countries such as Canada, the population's perception of the effects of logging industry is predominantly negative, because human communities are aware of the risks resulting from intensive logging (FAO, 2001).

The ongoing debates on forest protection highlight the need to develop a Green Economy to the detriment of intensive exploitation or deforestation for agricultural land use depend on the interaction of several actors, such as the quality of government, forest Law Enforcement Systems and implementation of environmental policies, business environment and Civil Society (Tomich, Thomas \& van Noordwijk, 2004).

Many countries have understood the benefits of applying higher protection legislation, the goal being the total or partial preservation, as well as taking advantage of the benefits of forest environmental services. This approach is thought to be appropriate for ecosystem-dependent communities (Larson \& Dahal, 2012; Meijaard et al., 2013). An example of higher protection in the inhabited areas is Austria, which since the modern era applies the principles of sustainable forestry, the purposes being to protect local mountain communities against erosion processes, to maintain biodiversity and to reduce forest degradation. Starting with 1975, although it recognizes the high degree of ecological education and the social responsibility of the population, Austria has applied, especially in the mountain area, restrictions to ownership rights in the 'public interest' by offering the owners financial compensation, in order to cover management costs (Weiss, 2001).

Other countries, such as Germany, China, Indonesia, Bosnia and Herzegovina, and Russia, have improved their forest protection legislation, with the aim of controlling illegal logging and of promoting responsible wood harvesting (World Bank, 2006).

Applying a very high protection by including considerable forest areas in categories such as natural parks, national parks, protected areas, historical, cultural and environme ntal sites or natural reserves represents a measure used by a number of countries in Asia-Pacific, Europe, North America or Africa (Durst, Enters, Tan \& Waggener, 2001; Mbatu, 2009). In certain situations, the special status of these areas contradicts the economic needs of local communities, which own them but cannot harvest them economically (Turner et al., 2012).

From the perspective of involving the local population in forest management, the situations are extremely diverse. Thus, the populations in the equatorial environments, which perpetuated an autarchic life system, totally dependent on the benefits offered by the forest, and had a life traditionally oriented towards responsible economic exploitation and environmental services, are worried and dissatisfied with the intensive economic activities that impact forested areas (Hecht, 2011; Meijaard et al., 2013; Walker \& Simmons, 2018). 
In the countries whose legislation is oriented towards sustainable development, sanctioning non-compliant logging, forest owners show a pro-environmental attitude. This behavior is closely related to the situation in which the state offers financial compensations to make up for the restrictions to harvest forest ecosystems or for the costs related to forest guarding and maintenance.

As far as Romania is concerned, forest owners are often sanctioned for improper management, excessive exploitation or lack of concern, although these people have no direct economic benefits, while those responsible for felling the trees are never sanctioned (Vasile, 2020). The exclusive economic interest is specific only to the people that do not own the forest, which are indifferent with regard to conservation (Bouriaud \& Marzano, 2012).

\section{2. Study area}

\subsection{General background}

In 2015, the Ministry of Environment published the risk maps on the prevalence of uncontrolled logging, with the corresponding attributes, based on a minimum methodology and specific data for the years 2013-2014, where Argeş and Mehedinţi counties are among the top four most affected administrative units of Romania (Fig.1: A).

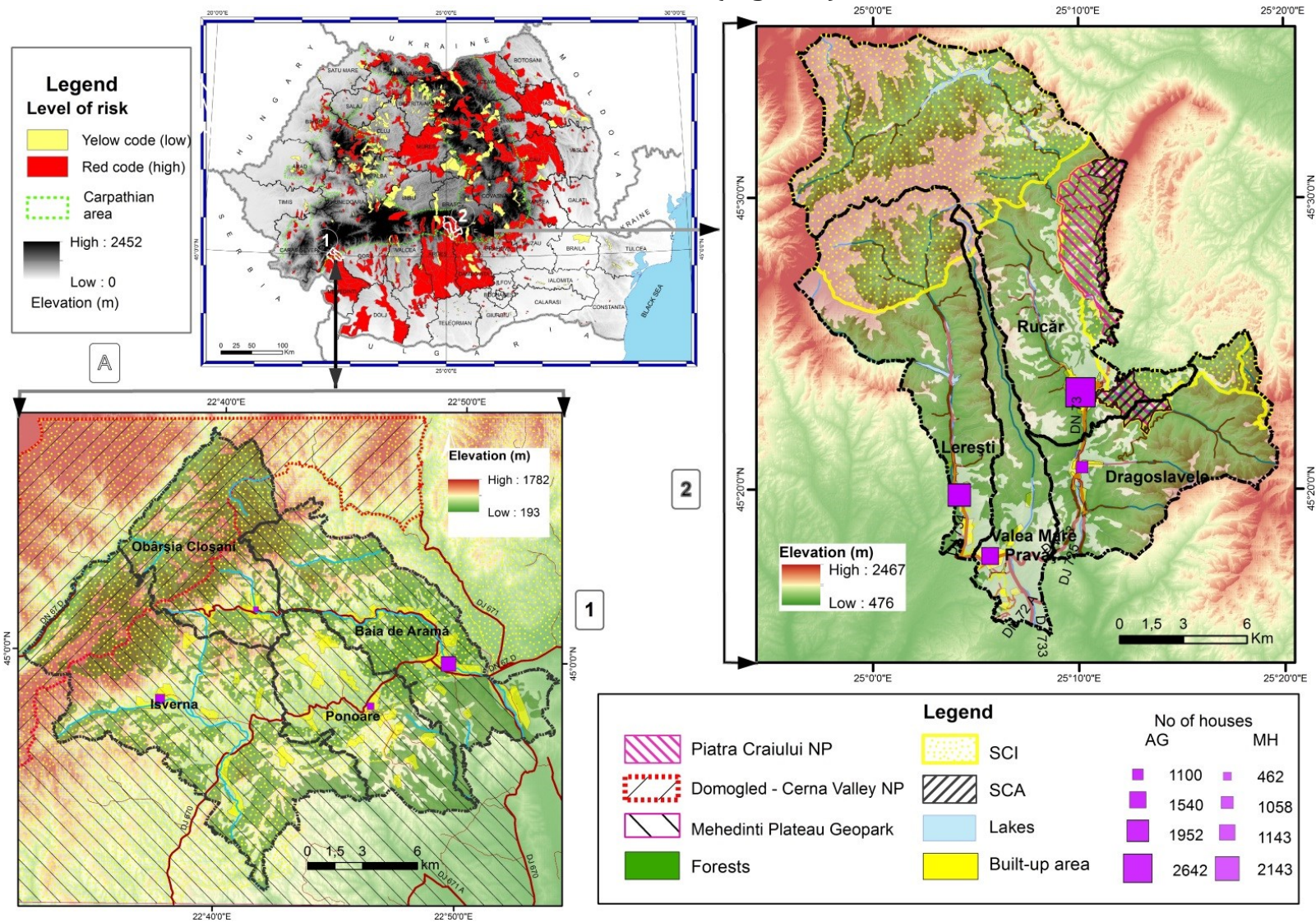

Figure 1. Risk map of uncontrolled logging prevalence in 2015 (A) and the forest-protectionconsumers data of the investigated administrative units in high riskareas. 1. Mehedinţi County. 2. Argeş County. (Processed after the information collected from the Ministry of Environment, 2015 and NIS, 2011).

The study has taken into account the extension of these counties in the Carpathian area and the existence of differences in forest management, as in the Argeş County the forests are owned 
by the local communities, while in the Mehedinţi County state property is prevailing. Other elements taken into account have been the level of economic development, the similarities in the orientation towards tourist use, and the existence of protected areas belonging to category $\mathrm{V}$ in IUCN (Fig.1: 1, 2).The investigation covers eight administrative-territorial units from the two counties, which are included in the category of areas vulnerable to risk (Fig. 1: A).

The total surface of the studied area is $942.82 \mathrm{~km}^{2}$, being a living space for 28,054 people (NIS, 2020), not equally divided between the two counties as Argeş has a higher proportion (over 61\%) in both cases. The average degree of afforestation in 2020 is clearly higher in Argeş (67.5\%) than in Mehedinţi (42.4\%) (NIS, 2020), and the forest ownership in Argeş is 60\%, compared to 32\% in Mehedinţi (NIS, 2020). Theoretically, the pressure on the forest through domestic uses is reduced, the housing stock having on average 2-3 people per property (Figure 1), and two administrativeterritorial units use different heating fuels: Argeş natural gas and Mehedinţi coal and wood.

The two groups of settlements belong to counties with different GDP (Argeş: Euro 38.9 million; Mehedinţi: Euro 10.6 million) (NIS, 2020), but both having rather similarsmall employment rates (between 5 and 8\%), except for Baia de Aramă (17\%) (NIS, 2020). The rate of forest per inhabitant, the average is lower in Mehedinţi (1.3 ha/inhabitant) and bigger in Argeş (2.3 ha/inhabitant).

\subsection{Changes in the forest cover}

Compared to the reference year, 1990, the dynamics of forest cover has recorded totally opposite tendencies in the two study areas, respectively of growth in Mehedinţi County (Figure 2. I), where, the area is partially protected and managed by Romsilva, while in Argeş County is of shriking under various administrators and the protected areas are small (Figure 2. II). The positive dynamics in all administrative units in Mehedinţi for all types of forests meant increases by about $10 \%$ in three decades in the northern areas, where the afforestation index is two or even three times higher than the national average, and e $5 \%$ in the southern, less forested perimeters (Figure 2.b, c, d). In the northern area of Argeş County, one can see a higher decline in coniferous and mixed forests and a lower one in deciduous forests, although the afforestation-deforestation ratio results in the analyzed period in a loss of only $2 \%$. Two of the communes that have a lower afforestation index, relatively close to the national average, register decreases of forest areas, respectively Rucăr, which has over 1/3 of the total decreases of the Argeș, and Valea Mare Pravăţ. Other two settlements have better averages and, overall, show a forest expansion (Figure 2. f, g, h).Viewed as feedback to local communities, the balance in the period 1990-2012 of forest areas was related to the average demographic size of the same period, when an average increase of $0.186 \mathrm{ha} /$ inhabitant was recorded in Mehedinţi and an average decrease of $-0.021 \mathrm{ha} /$ inhabitant in Argeş. A good index was noticed in two administrative-territorial units belonging to the two areas (rank 1-2). For other four, the index was favorable (rank 3-6) and for two more, it was negative (Table 1).

Table 1. Balance rank of forest areas (ha/inhabitant)

\begin{tabular}{llllll}
\hline Mehedinți & B & Rank (Rank in total) & Argeș & B & Rank (Rank in total) \\
\hline Baia de Aramă & 0,102 & $3(4)$ & Dragoslavele & 0,326 & $1(2)$ \\
Isverna & 0,157 & $2(3)$ & Lereşti & 0,034 & $2(6)$ \\
Obarşia Cloşani & 0,636 & $1(1)$ & Rucăr & $-0,165$ & $4(8)$ \\
Ponoare & 0,045 & $4(5)$ & Valea Mare Pravăţ & $-0,092$ & $3(7)$ \\
\hline Average & 0,186 & & Average & $-0,021$ & \\
\hline
\end{tabular}

Source: the authors own calculations. 

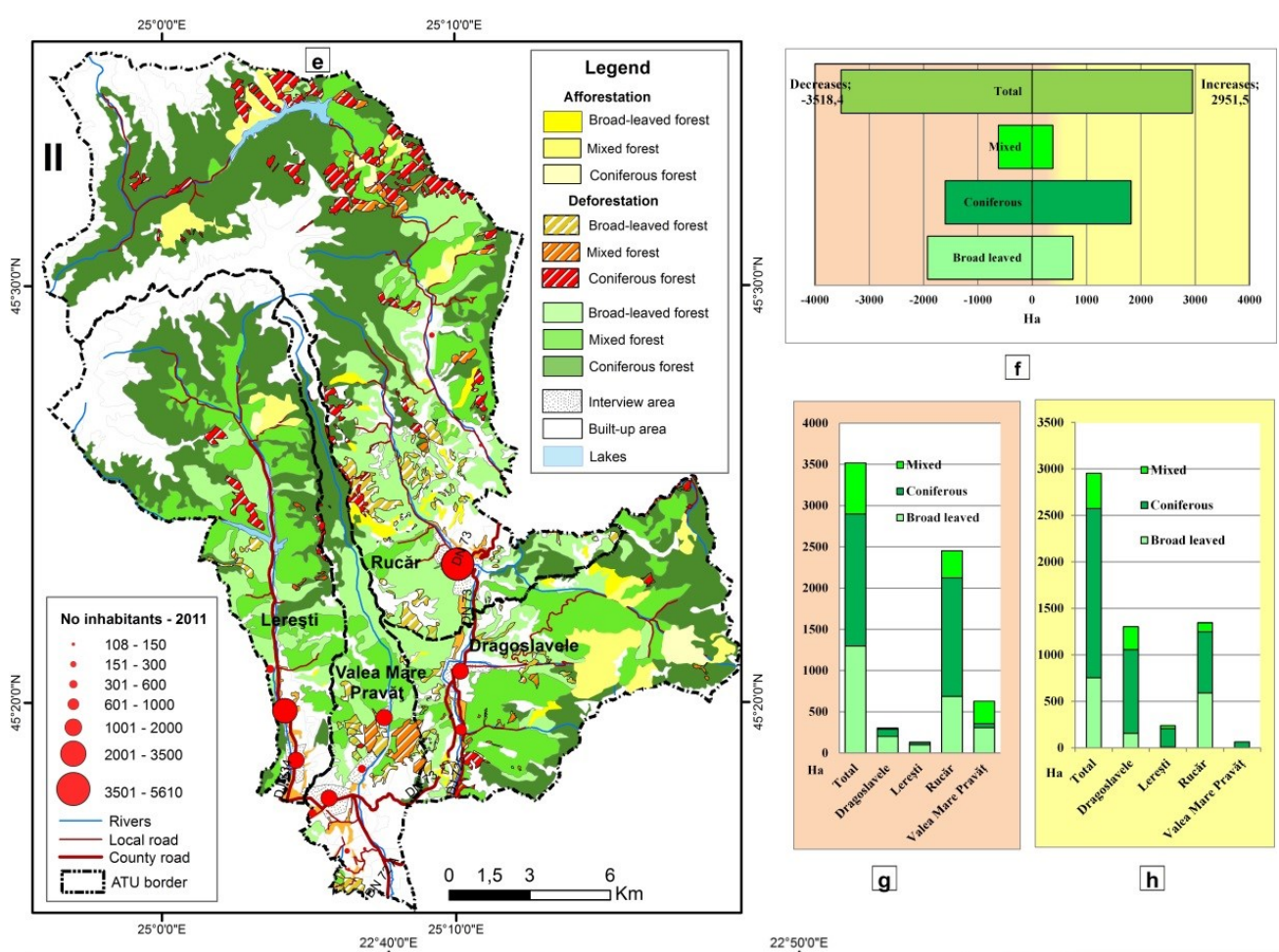

f

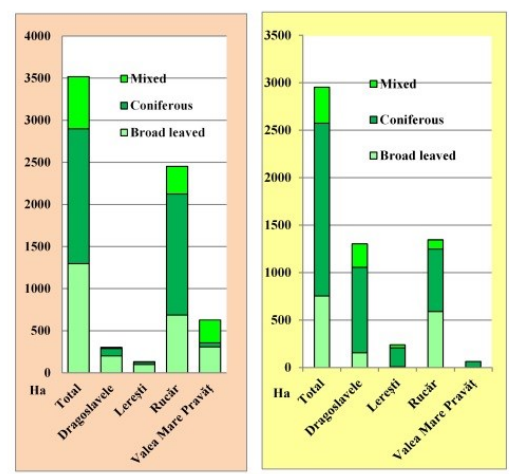

g

h

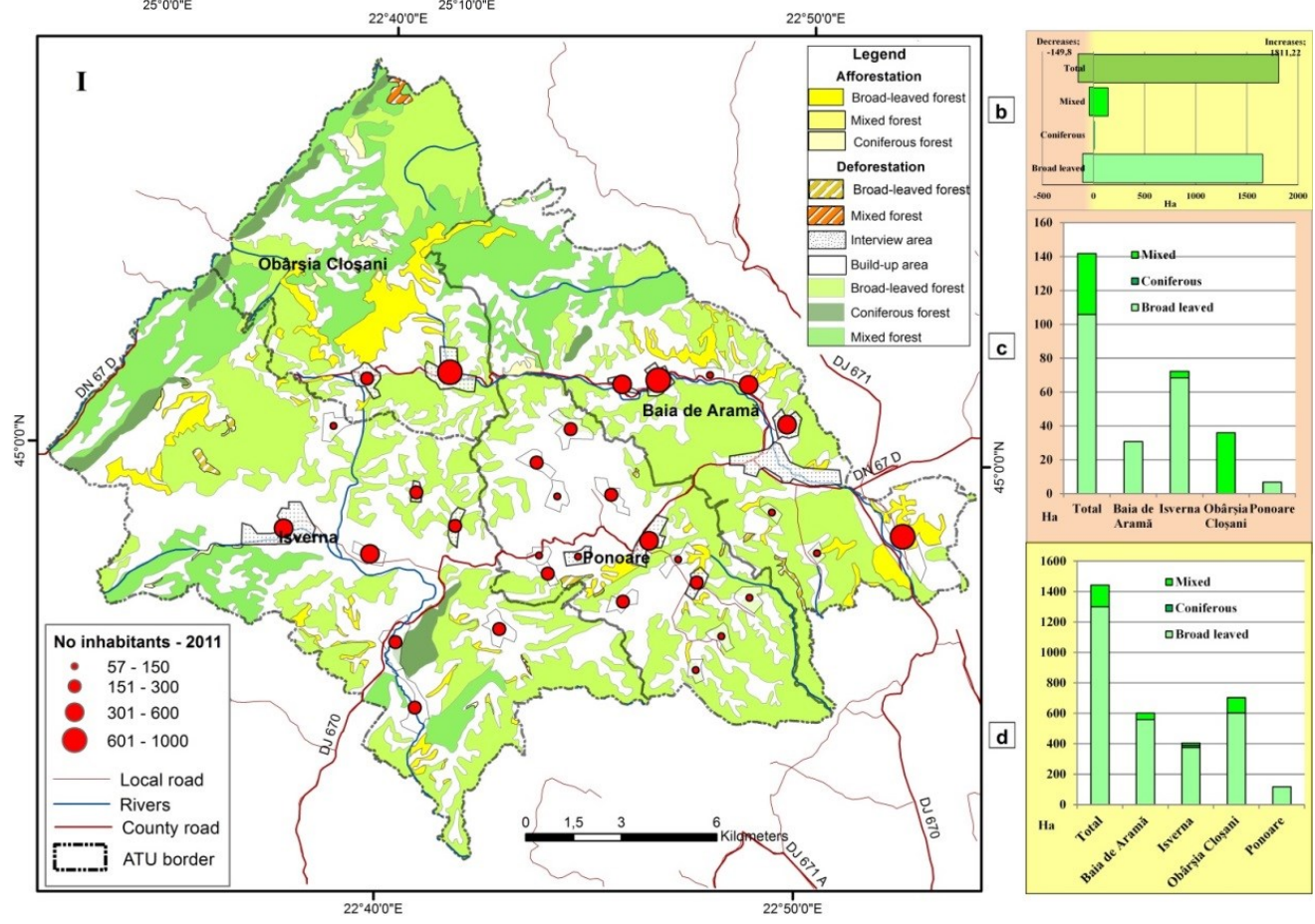

Figure 2. Forests dynamics Mehedinţi (I), and Arges (II). Afforestation and deforestation between 1992 and 2012 (a, e), by type of forests (b, f), decreases by territorial-administrative units (TAU) (c, g), increases by TAUs (d, h). (Processed by authors after CLC 2012, 1990, and NIS data-Population Census, 2011.

\section{Methods and materials}

To examine local communities'perception regarding their involvement potential in the management of local heritage forests we used a qualitative survey applied as a naturalistic inquiry (Bowen, 2008; Matei et al., 2018) in mountain villages grouped in 8 administrative units 
from two counties, Mehedinţi and Argeş, both in Southern Carpathians (Figure 1). We prepared a semi-structured interview, which is more flexible (Berg, 2009), divided in three sections: environmental-forest knowledge, perceptions/practice and attitudes. The first 6 questions focused on the demo-social characteristics of the respondents; 2 were landmark questions, meant to test the degree of interaction with the forests in the locality; 10 questi ons to assess the level of knowledge about forests; 10 questions were about forest management practices; and 5 focused on attitude. The questions were validated by groups of two: forest engineers, forest technicians, environmentalists and economists. The interview was applied in the territory by the authors, who were accompanied by volunteers who knew the territory very well. The data were recorded only in writing, in order to eliminate the suspicions often encountered in the preparatory and acceptance conversations.

Some of the items were filled in by the interviewees themselves, namely the sociodemographic data and the second part of the interview which included closed answers, based on a five-step Likert scale (1 - very weak, 5 - very good) or binary ( $0-1)$. The interview started from a discussion on the local horizon (distance to the forest, the name of the nearest forest, tree species, etc.) and then took into account the farther horizon, in order to capture the three dimensions/sections pursued.

The interviewed persons were selected by snowball sampling technique (Kogan et al., 2011), respecting ethical principles (Brinkmann \& Kvale, 2005) and alleviating possible conflicts (Wood, 2006). The finally confirmed sample includes 64 respondents, equally divided on the two counties, but slightly exceeded by men (59.3\%), which is in consensus with the reality of Romania, where man is the head of the family. However, the structure of demographic parameters differs between the two analyzed regions, the respondents being younger in Mehedinţi County (39.34 years old) in comparison with Argeş County (48.84 years old). Moreover, the level of education is higher and forest properties are larger in the western part of the Carpathians (Mehedinţi County), while the Argeş County shows a wider range of occupations (Table 2).

Table 2. Demographic profile of the sample.

\begin{tabular}{|c|c|c|c|c|c|c|c|}
\hline Region & $\begin{array}{c}\text { Age } \\
\text { Means }\end{array}$ & $\begin{array}{l}\text { Age interval } \\
\text { and groups }\end{array}$ & $(\%)$ & $\begin{array}{l}\text { Gender } \\
\text { M (\%) }\end{array}$ & Profession & Property & Education \\
\hline $\begin{array}{l}\text { Total } \\
(\mathrm{N}=64)\end{array}$ & 44.09 & $\begin{array}{c}{[18-78]} \\
18-35 \\
36-60 \\
\text { Over } 61\end{array}$ & $\begin{array}{l}100(\mathrm{~N}=64) \\
32.81 \\
43.85 \\
23.43\end{array}$ & $\begin{array}{l}59.3(\mathrm{~N}=38) \\
14.0 \\
28.12 \\
17.18\end{array}$ & $\begin{array}{l}7 \text { students } \\
12 \text { farmers } \\
10 \text { retirees } \\
4 \text { administrators } \\
10 \text { workers } \\
21 \text { education }\end{array}$ & $\begin{array}{l}25 \text { yes } \\
39 \text { no }\end{array}$ & $\begin{array}{l}5 \text { primary school } \\
32 \text { medium } \\
27 \text { graduate }\end{array}$ \\
\hline $\begin{array}{l}\text { Mehedinţi } \\
(\mathrm{N}=32)\end{array}$ & 39.34 & $\begin{array}{c}{[18-76]} \\
18-35 \\
36-60 \\
\text { Over } 61\end{array}$ & $\begin{array}{r}50 \\
18.75 \\
23.43 \\
7.81\end{array}$ & $\begin{array}{l}28.12(\mathrm{~N}=18) \\
7.8 \\
14.07 \\
6.25\end{array}$ & $\begin{array}{l}5 \text { students, } \\
9 \text { farmers } \\
2 \text { workers } \\
1 \text { administrator } \\
5 \text { retirees } \\
10 \text { education }\end{array}$ & $\begin{array}{l}14 \text { yes } \\
18 \text { no }\end{array}$ & $\begin{array}{l}1 \text { primary school } \\
15 \text { medium } \\
16 \text { graduate }\end{array}$ \\
\hline $\begin{array}{l}\text { Argeş } \\
(\mathrm{N}=32)\end{array}$ & 48.84 & $\begin{array}{c}{[18-78]} \\
18-35 \\
36-60 \\
\text { Over 61 }\end{array}$ & $\begin{array}{l}50 \\
14.0 \\
20.31 \\
15.62\end{array}$ & $\begin{array}{l}31.25(\mathrm{~N}=20) \\
6.2 \\
14.06 \\
10.94\end{array}$ & $\begin{array}{l}2 \text { students } \\
8 \text { workers } \\
3 \text { farmers } \\
3 \text { administrators } \\
5 \text { retirees } \\
11 \text { education }\end{array}$ & $\begin{array}{l}11 \text { yes } \\
21 \text { no }\end{array}$ & $\begin{array}{l}4 \text { primary school } \\
17 \text { medium } \\
11 \text { graduate }\end{array}$ \\
\hline
\end{tabular}

Therefore, we can start from the premise that at such an average age their life experience about the investigated issue is reasonable, in the context in which everyone has forests nearby. The distance to the wooded areas varies from $0.12 \mathrm{~km}$ to $10 \mathrm{~km}$, with an average of $2.6 \mathrm{~km}$, the 
values being lower in Mehedinţi and higher in Argeș. The forests are made up predominantly of deciduous trees, and 39\% of the interviewees are forest owners.

Data analysis was based on descriptive statistics tools (Frequency, Chi Square test and clustering method), to which the dominant opinion index (DOI) was added.

The topics proposed to be analyzed by descriptive statistics (SPSS v.2019) related to sociodemographic variables (age category, gender, education, occupation), to the status of the respondents (forest owners or not) and to their place of residence in the two geographical areas.

The DOI method was chosen to capture the intensity of opinions. Methodologically, the argument for calculating a DOI is related to the quantification of the positive, negative and neutral opinions expressed by the respondents. DOI is obtained based on the formula (FvO-UvO) * $(100$ $\mathrm{NeO}$ )/100 (Hofstede, 1991). The value of the index oscillates on a scale of \pm 100 , in the range +100 for dominant favorable opinions (FVDO), and -100, for dominant unfavorable opinions (UvD0). This was applied in order to quantify the perception on the elements regarding the activity of forest administrators, on the forest legislation in Romania and on the condition of the forests in the administrative-territorial units.

The data obtained from the answers to the open-ended questionsrequired their selection and binary coding for processing by agglomerative hierarchical clustering, Ward's method, Euclidean distance and SD \pm 1 , which has the advantage that each variable is assigned in a cluster (PătruStupariu et al., 2016), while the dendogram shows the possible relationships. Silhouette method was used to determine the number of clusters (Rousseuw, 1987), taking into account a quality $\geq$ 0.5 , which allowed the visualization of the clusters size and the assessing of their predictions. All computations were performed using SPSS v. 19.

In order to analyze the answers on real bases, the dynamic maps of the forests for the reference period 1990-2012 were elaborated in GIS, based on the CLC, adjusted with satellite imagery. The data on population and households was collected from the 2011 Population and Housing Census, which shows data at the level of component localities of the administrativeterritorial units.

\section{Results and discussions}

\subsection{Forest defintion and benefits knowledge of owners' vs non-owners}

The analysis of the significance assigned to forest definition (FD) by the study participants is based on the answers to the direct question, which required them to mention the first words/ideas/short definitions that come to their mind when they think of "a forest".

Almost $2 / 3$ of them (85.9\%) used keywords that emphasize the role of the forest in the environment: "an ecosystem, oxygen source, green lung", "habitat", and "green gold", opinion outstanding among the other expressed opinions. For this reason, we appreciate that these p eople may form a group called „Pro-environmental Forest Definition” (Pe-FD) (Figure 3).

Compared to the profile of the people who share this opinion, we deem that there is a weak association of this mental representation with subjects having a high level of education $\left(\chi^{2}(1)=\right.$ $5.05, \mathrm{p}<0.025$; Phi $=0.257, \mathrm{p}=0.038$ ), but a very strong association based on age, where young people and adults consider the forest as the main element of the environment, an ecosystem, a source of oxygen, or a "green gold" area $\left(\chi^{2}(1)=47.23, \mathrm{p}<0.000\right.$; Phi $\left.=0.852, \mathrm{p}=0.000\right)$.

In connection with the Pe-FD, the metaphoric expressions like "green gold", "green lung" or "oxygen source" (42.7\%) were used exclusively by the highly educated interviewees, and by some 
of those with middle-level studies, but this opinion was prevalent among the forest owners.

A second category included in Pe-FD aimed at empirical descriptions. Thus, $43.8 \%$ of the respondents focused on the forest as a surface with trees, shrubs and plants, naturally growing or planted by man, which is the dominant reality in the area of the respondents from Mehedinţi, while others defined it as a "wildlife housing area". The latter representation is specific for the people with primary and middle-level education, as well as for those who are not land owners.

The rest of the definitions (14.1\%) have a social and economic orientation (Se-FD), from which the forest stands out as a recreational and leisure area grouped under "recreational function definition", which is specific for non-owners. The forest is also associated with a source of material benefits, either in the form of construction material or in the form of heating fuel (opinion expressed by categories, owners and non-owners).

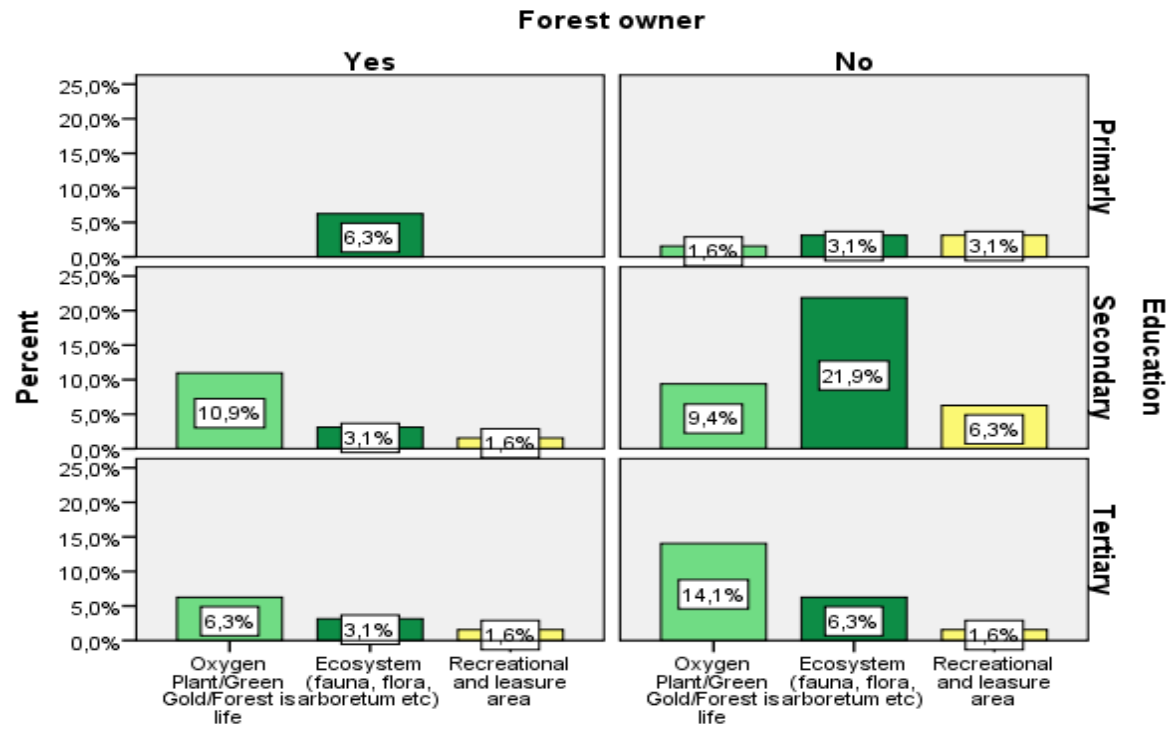

Figure 1. Dominat definition of forest by education and forest land ownership.

The identification of the representations of the participants in the study on the benefits of the forest (FB) was made based on their perception on the role that forest plays for the local community, with all the benefits associated with it.

The FB emphasizes environmental knowledge because respondents highlight "the forest as the main source of clean air, oxygen, reducing pollution and implicitly as a source of health through the quality of air provided". These benefits were appreciated by $65.5 \%$ of the interviewees, especially non-owners (Figure 4. A).This opinion is moderately associated with the age of the respondents $\left(\chi^{2}(1)=4,447, p<0.035\right.$; Phi $\left.=0.253, p=0.035\right)$, who being younger, attribute this significance to the forest. This benefit of the forest is moderately associated $\left(\chi^{2}(1)=5.031, p\right.$ $<0.025$; Phi $=0.268, \mathrm{p}=0.025$ ) also with people's occupations, who actually mirror their level of formal education. Thus, the people who currently have occupations or had occupations in the past that require higher education value more the significance of forests with regard to its ecosystem function. The property right over the forest and the ecosystem benefit offered by it explain the following situation: people who do not own forest areas rather value the benefits generated by the forest as a green resource $\left(\chi^{2}=6,935, p<0.008\right.$; Phi $\left.=0.310, p=0.028\right)$, while the owners attribute the forest other meanings, too. In this sense, it can be concluded that the population is oriented towards pro-ecosystem forest benefits. In this case, the socio-cultural profile does not introduce significant differences (Figure 2. A). 
Economic benefits by capitalizing on timber through trade or by using it in construction are associated primarily with the status of forest owners, which can be considered pro-economic benefits. Thus, the value of the association coefficient $\chi^{2}$ draws attention to the existence of a low association $\left(\chi^{2}=5.050, \mathrm{p}<0.025\right.$; Phi $\left.=0.269, \mathrm{p}=0.025\right)$ between owning a forest property and capitalizing on it in a strictly economic sense.

Likewise, the size of the economic benefits generated by the forest is associated with the age related component of respondents, who, as they get older, appreciate it more. The respective association is low $\left(\chi^{2}=4,689, p=0,027\right.$; Phi $\left.=0,264, p=0,027\right)$.

Lower income occupations (agricultural worker, retired, keeper) is associated with the economic benefits of the forest $\left(\chi^{2}=4,304, p=0.038\right.$; Phi $\left.=0.249, p=0.038\right)$. The economic activities carried out in rural areas, and especially the occupations through which the wood is processed to be used as building material, are mainly the prerogative of men, which is why the gender of the respondents is associated with the economic perspective on the forest. Thus, a moderate association was identified $\left(\chi^{2}=7.743, p=0.005\right.$; Phi $\left.=0.326, p=0.005\right)$ between the male gender and the appreciation of the economic benefits offered by the forest (Figure 4 . B).

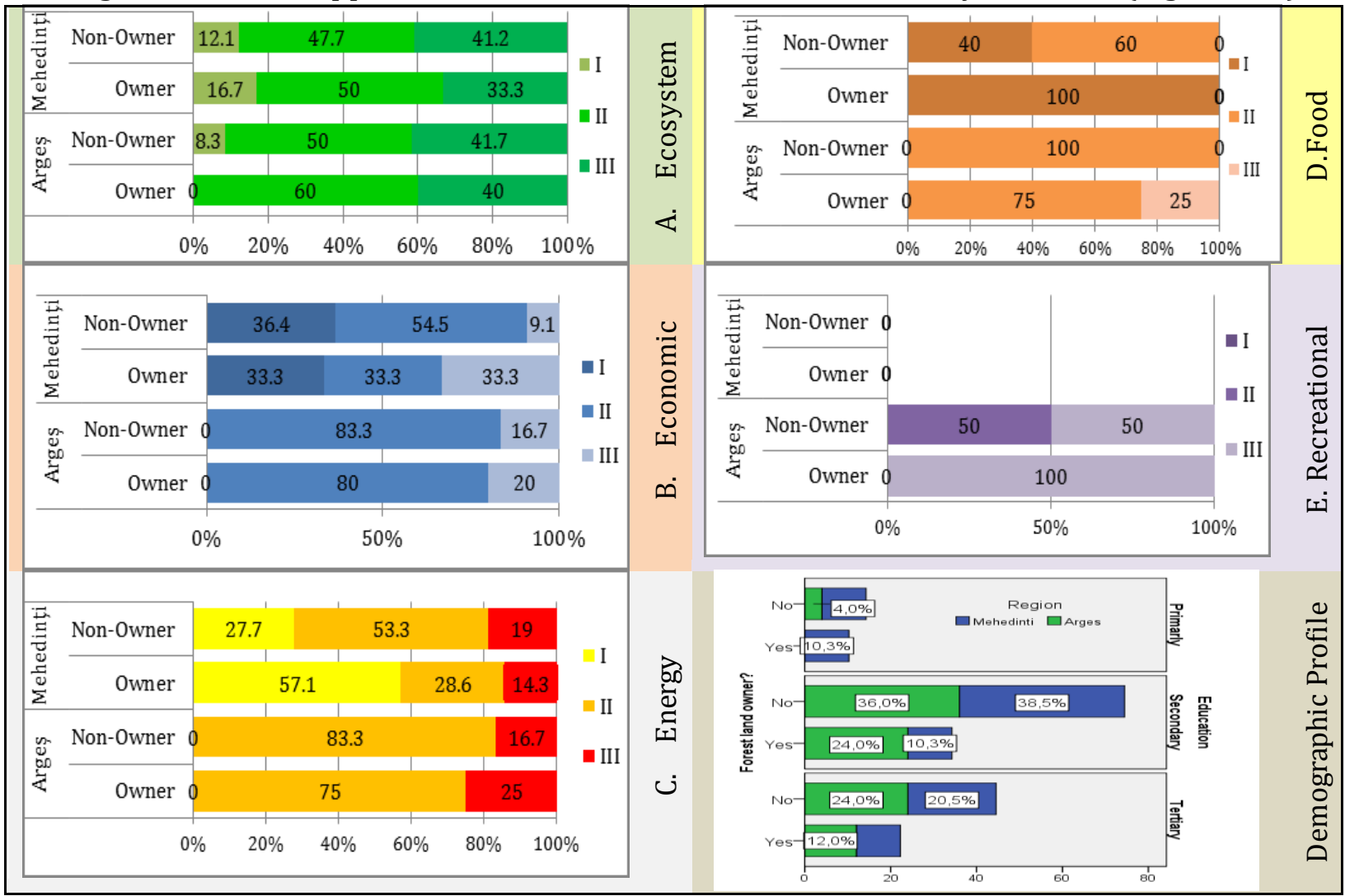

Figure 4. Perception of local communities on the benefits of the forest correlated with education, property and region of residence.

The capitalization of the energy benefits of the forest, respectively, the capitalization of wood mass as a source for heating or commercialization for heating was outstanding among the males, who at the level of the traditional-rural household are responsible for the heating source. The existing correlation is low $\left(\chi^{2}=5.015, p<0.025\right.$; Phi $\left.=0.268, p=0.025\right)$ (Figure 2. C). Beneficiile legate de valoare alimentară este mai prezenta in perceptia comunitatilor mehedintene, le care au 
studii reduse, indiferent de starea de propretate sau nu a padurii $\left(\chi^{2}=4,000, p<0,046\right.$; Phi $=$ $0,333, p=0,025$ ) (Figure 4. D.).

The benefits related to food value were more present in the perception of the Mehedinţi communities, with low-level education, regardless of whether the respondents were owners or non-owners $\left(\chi^{2}=4,000, p<0.046\right.$; Phi $\left.=0.333, p=0.025\right)$ (Figure 4. D).

The aesthetic benefits of the forest were not identified in the perception of any participant, but they can be an attribute of economic capitalization through tourism, an aspect revealed only by the communities of Argeş County, lying along the Bran-Rucăr tourist axis (Figure 4. E.).

The opinions expressed on the exploitation of forest areas and the consequences of this exploitation can be formed on the basis of experience and in connection with the level of knowledge of the problems, which is acquired through education and culture.

The exploitation of forests is a reality, but the main interest of this section has been the way in which this activity is reflected in the opinion of the respondents. By comparatively analyzing their opinions, we can appreciate that in the two analyzed regions there are different profiles of forest harvesting. Thus, the perception of the respondents from the Mehedinţi area highlights the fact that almost half of the forest area is exploited by economic agents (47.6\%), compared to the Argeş area, where approximately one third of the respondents (35\%) perceive that forest resources are mainly capitalized by the local authorities and competent institutions. Relatively similar weights regarding forest exploitation by local community actors (villagers, forest owners, community, etc.) were expressed in both investigated regions (Figure 5).

The respondents' differences in perception may reflect a state of affairs or the lack of information due to deliberate confusion. Thus, for each of the regions there is a dominant category of actors involved in forest capitalization, which are either economic agents (Mehedinţi) or local authorities (Argeş).

Analyzing the possible consequences associated with an intensive harvesting, four distinct types of risks were identified, each having a degree of specificity depending on the geographical area. Beyond risk specificity, we can see that two of the mentioned risk categories can be deemed as having a local character. These two directly target the communities to which the respondents belong (landslide risk and flood risk), while the other risk categories have a rather global character (ecosystem destruction, pollution increase, temperature increase) (Figure 6).

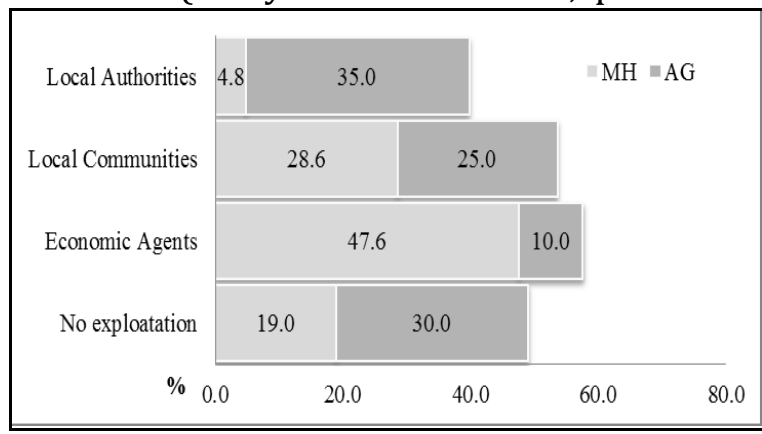

Figure 5. Perception related to deforestation risks by forest's actors

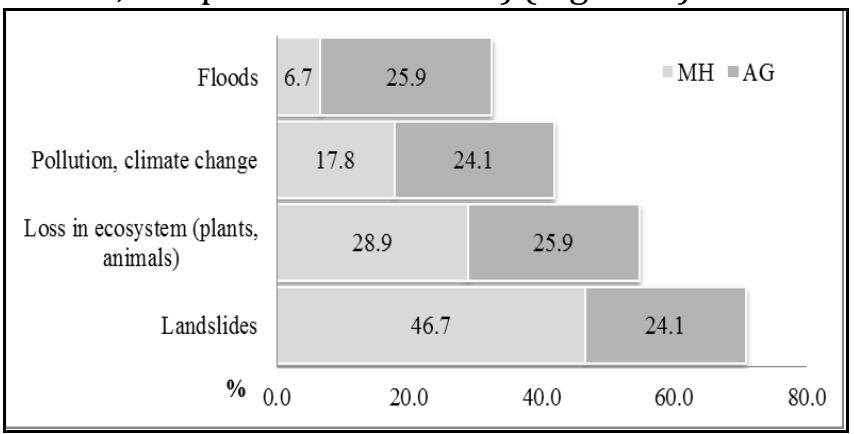

Figure 6. Perception related to deforestation effects on the environment

Following the descriptive analyses by agglomerative hierarchical clustering it was observed that the level of education was the most representative element. Consequently, three groups of variables were taken into account: forest definition (FD), forest benefits (FB) and excessive logging risk (ER). For the first topic (FD), only 58 people provided an analyzable answer. In this case, cluster quality was fair (Average Silhouette; $\mathrm{S}=0.5$ ) and the dend ogram by Ward Linkage 
cut 4 clusters, as follows: "environment quality for life" ( $\mathrm{N}=28)$, "scientific background" $(\mathrm{N}=18)$, "economic value" $(\mathrm{N}=7)$, and "environmental and economic value" ( $=5)$.

The analysis of the correlation between education and ecosystem benefits (FB), identified by the interviewees, based on $S=0.5$, allowed the generation of 5 clusters. The strongest group forms a cluster called "production-economic and energetic values" (22.2\%), then comes one that refers to the services of "oxygen-production" (20.6\%) and "cultural tourism" (17.5\% ), followed by two other clusters which put emphasis on "support" (fauna and flora) and "regulation”.

As far as the third group of variables (ER) is concerned, nine answers do not identify the real consequences. It was the group which had a medium level of education, for which the dendogram included 4 clusters, whose silhouette plot showed fair quality $(S=0.5)$ (Table 3). The representativeness is almost equal between the groups called "climate change" $(\mathrm{N}=13)$, "landslides" ( $=10)$ and „floods" ( $=9)$, while the rest coupled the three consequences among them.

Table 3 Quality of clusters regarding the knowledge about the fores

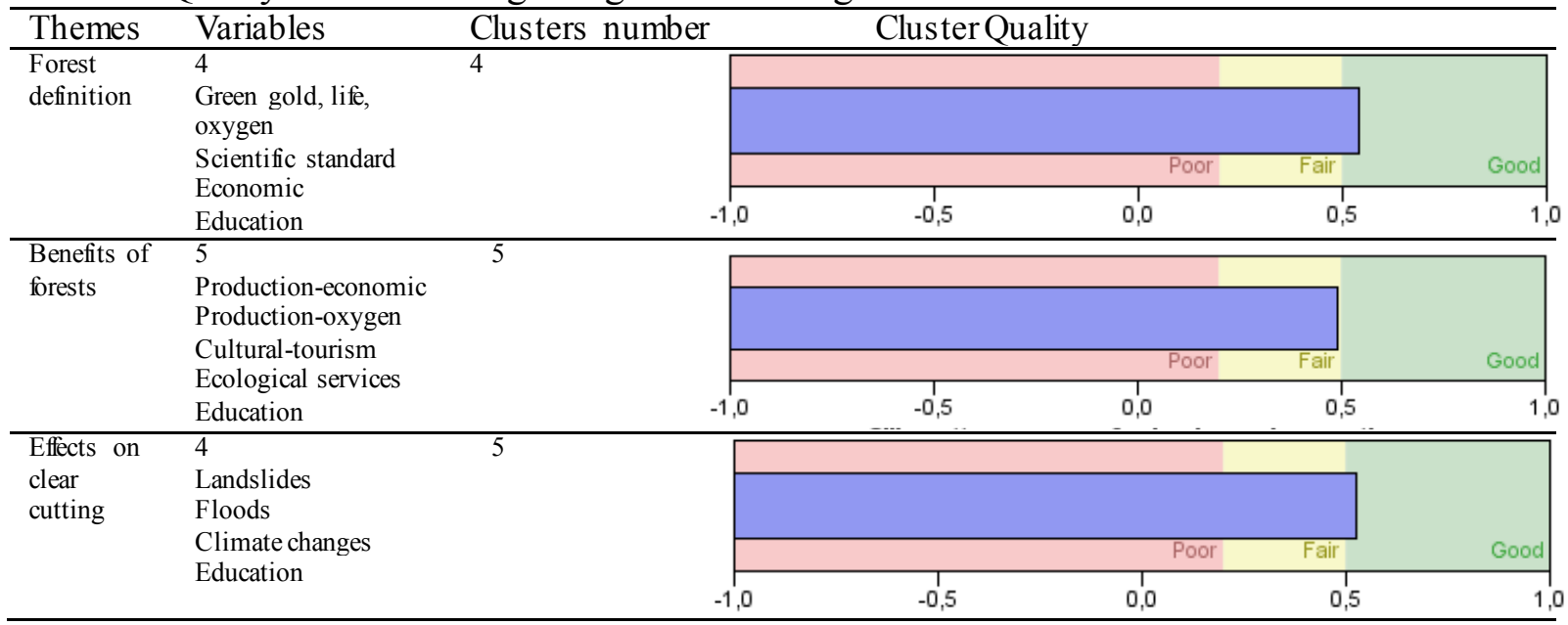

\subsection{Perception regarding the state of forests}

The data collected for perception focused on assessing the state of the forest in the administrative-territorial units, the efficiency of forest managers, and forest legislation. Overall, the perception is mostly negative. About $40 \%$ of the interviewees have a perception related to the state of the forest in accordance with the dynamics of the areas calculated for the analyzed period (Figure 7), during which the administration belonged to Romsilva. Of th ese, 50\% are people who have frequent contact with forest environment, but who have a middle-level education. Comparing the two regions, we saw that there were differences of perception related to the analyzed aspects, which were more favorable in the administrative-territorial units belonging to the Mehedinţi County.

The status of owner and non-owner of forest areas also marks the way in which the respondents relate to the aspects regarding the "state of the forest in the commune", respectively the "activity of the forest administrators". Thus, forest owners express a predominantly neutral attitude when assessing the "state of the forest" compared to those people who do not own forest areas, whose opinion is rather oriented towards dissatisfaction.

The dominant opinion shared by forest owners regarding the forest management activity has slightly positive values, compared to the opinions expressed by the respondents who do not own forest areas whose assessments are predominantly negative. The difference between the two 
opinions could be explained by the fact that forest owners are more reserved due to in -depth knowledge about forest maintenance issues, resources needed difficulties or specific problems that arise in assessing its "state" or "condition". This time as well, the gap between the dominant opinions of the two categories of respondents, forest owners or non-owners, can be explained by the knowledge of the specific character of this activity, as well as by a subjective assessment of the situation.

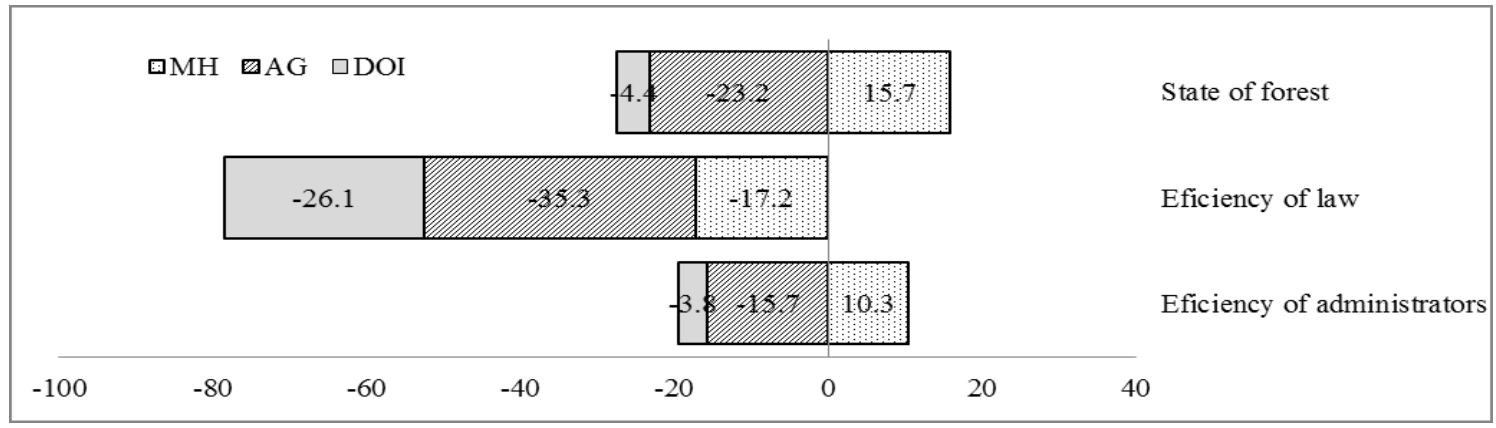

Figure 7. DOI of respondents regarding the state of forests, administrators and forestry's law efficency

The convergence of the opinions expressed by the respondents, regardless of whether or not they own forest areas, is highlighted in terms of the dissatisfaction expressed regarding the national legislative framework that regulates the forestry regime in Romania. By comparison, people who are not in touch with the specific character of the forest maintenance activities, rather express a state of dissatisfaction.

\subsection{Perception and attitude on community involvement in SFM}

The degree of involvement of the respondents shows that both owners and non-owners would be interested in getting involved in SFM, especially in conservation and protection activities. The volunteering rate is higher in the communities from Argeș county, a predictable aspect based on the type of community property and the experiences given by this status. The lack of interest is shared by all levels of education. People with higher educa tion, but also the females with domestic occupation, decline their involvement in SFM (Figure 8).

The people in Mehedinţi County, who do not have forests, because the nearby woods are protected areas, believe that local population would be interested in participating in a large share in some SFM actions from the perspective of preserving the forest for future generations. By comparison, in the Argeş County opinions are equally divided. The owners from both areas, but especially those from Argeș, are more skeptical about the possible involvement of the inhabitants.

The respondents thought they would rather get involved in voluntary than in remunerated actions, being interested in cleaning the forest, planting trees, and monitoring illegal interventions. They also spoke in favor of the intensification of the public educational activities regarding forest protection. 


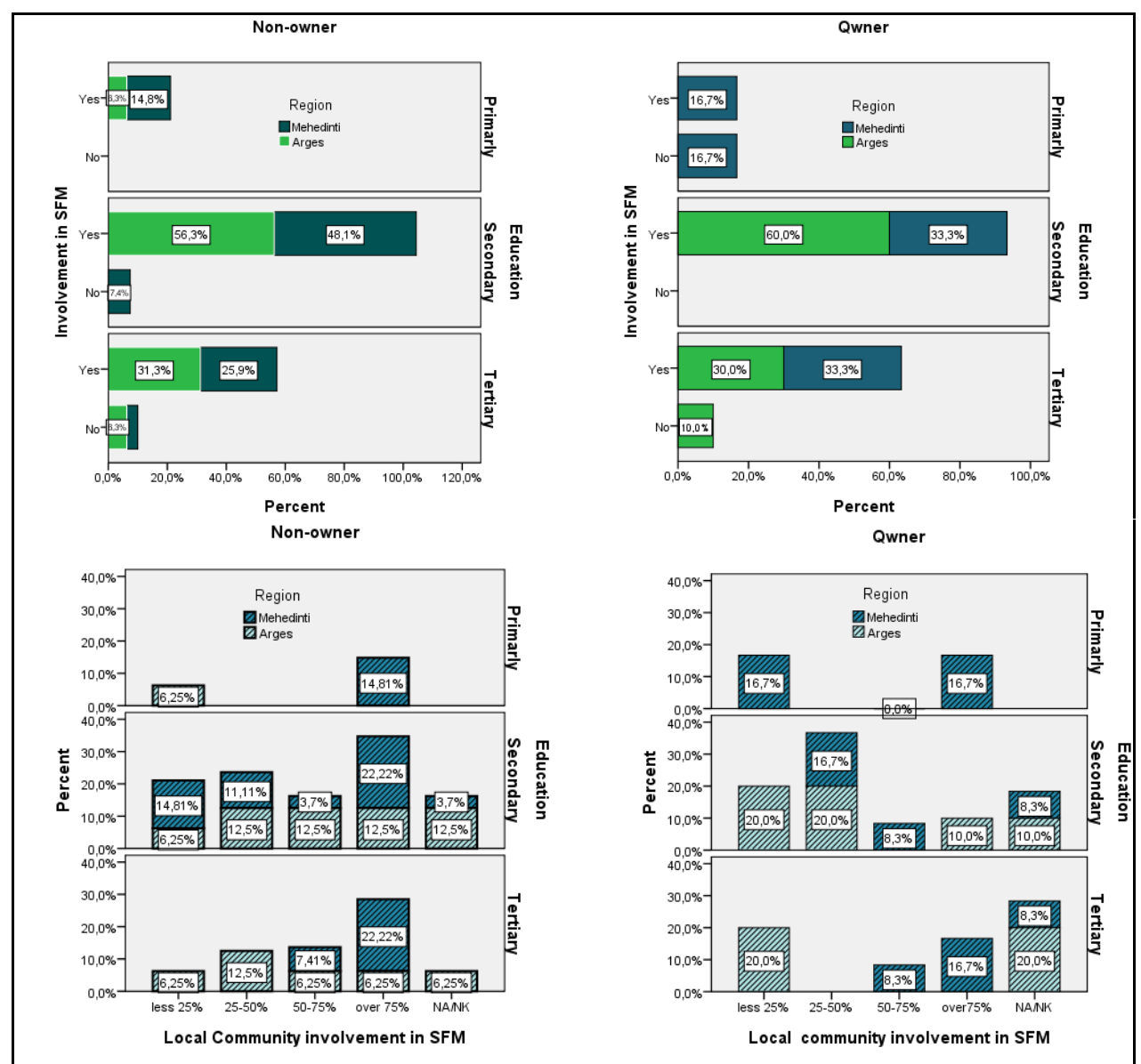

Figure 8. Perception regarding the respondent or community involvment in SFM

\section{Conclusions}

The local communities in the studied areas, although they have a heterogeneous level of education, show that they posses a comprehensive amount of information about the forest from an environmental, economic and administrative point of view. However, there is a slightly greater orientation of the young and adult population towards the emphasis on ideas related to forest functions: ecosystemic, cultural and recreational services.

The forest is associated with a source of material benefits, either in the form of construction material or in the form of heating for most forest landowners, as well as for some elderly people and some respondents in the cohort of those with secondary and primary education

Moreover, the elderly and those with limited financial resources appreciate the forest resource as a source of supplementing their household income.

The opinions expressed regarding the exploitation of forest areas and the consequences of this harvesting are different, as for each of the analyzed regions there is a dominant category of local actors involved in forest exploitation: economic agents (in Mehedinţi County) and local authorities (in Argeș County).

The improvement of forest condition depends directly on the involvement of the members of local communities in actions to protect forests and to reforest areas that have undergone excessive felling. Both the people with a high level of training and the younger ones are most aware of this aspect, due to their easier access to information. 
However, regardless of the region analyzed, the perception of the legislative framework governing forestry, exploitation and maintenance rights is predominantly negative. Obvious differences appear between the way in which the aspects related to the activity of the forest administrators are perceived, respectively in assessments regarding the state of the forest (in Mehedinţi county, the area subject to protection is larger, being administered mostly by Romsilva).

In terms of addressing the dysfunctions, local community members support the improvement of forest legislation and the increase of environmental responsibility by education, as they are willing to get actively involved in a well known range of voluntary activities (greening, reforestaion), not knowing that there are also deeper possibilities for intervention in FSM.

The study may be useful for the policy decisions and administrators that could be taken to improve forestry activities, but also for involving the local population, which is the one target of the sustainable management of the environment and, implicitly, of the forests.

\section{Acknowledgments}

The authors wish to thank the volunteers who accompanied them in the field campaign, as well as the respondents and the specialists consulted to clarify specific issues related to forest management.

All authors contributed equally to the design and completion of this study. There are no conflicts of interest between the authors.

\section{References}

1. Abrudan, I. V., Marinescu, V., Ionescu, O., Ioras, F., Horodnic, S.A., \& Sestras, R., 2009. Developments in the Romanian Forestry and its Linkages with other Sectors, Notulae BotanicaeHorti Agrobotanici ClujNapoca, 37(2), p. 14-21.

2. Badea, O., Bytnerowicz, A., Silaghi, D., Neagu, S., Barbu, I., Iacoban, C., Iacob, C., Guiman, G., Preda, E., Secelean, I., Oneata, M., Dumitru, I., Huner, V., Iuncu, H., Dinca, L., Leca, S., \& Taut, I., 2012. Status of the Southern Carpathian forests in the long-term ecological research network, Environmental Monitoring and Assessment, 184 (12), p. 7491-7515.

3. Barraza, L., 2001. Perception of social and environmental problems by English and Mexican school children. Canadian Journal of Environmental Education, 6, p. 139-157.

4. Barraza, L., \& Pineda, J., 2003. How young people see forests in Mexico: a comparation of two rural communities. Unasylva, 213, Vol. 54, p. 10-17.

5. Berg, B. L., 2009. Qualitative Research Methods for The Social Sciences. Allyn and Bacon, Boston.

6. Bouriaud, L., \& Marzano, M., 2012. Conservation, extraction and corruption: will sustainable forest management be possible in Romania? In: Gilberthorpe, E., (Coord.,), Natural Resource Extraction and Indigenous Livelihoods: Development Challenges in an Era of Globalisation, Ashgate International.

7. Bowen, G. A., 2008. Naturalistic inquiry and the saturation concept: a research note, Qualitative Research, Vol. 8(1), p. 137-152. DOI: 10.1177/1468794107085301.

8. Brinkmann, S., \& Kvale, S., 2005. Confronting the ethics of qualitative research. Journal of Constructivist Psychology, Vol. 18(2), p. 157-81.

9. Canadas, M. J., \& Novais, A., 2014. Bringing local socioeconomic context to the analysis of forest owners'management, Land Use Policy, Vol. 41, p. 397-407. http://dx.doi.org/10.1016/j.landusepol.2014.06.017.

10. Chwialkowska, A., Bhatti, W. A., \& Glowik, M., 2020. The influence of cultural valueson proenvironmental behavior, Journal of Cleaner Production, Vol. 268. p. 122305, doi: https://doi.org/10.1016/j.jclepro.2020.122305.

11. Durst, P. B., Enters, T., Tan, L. C., \& Waggener, T. R., 2001. Forests out of bounds: impacts and effectiveness of logging bans in natural forests in Asia-Pacific. FAO Regional Office for Asia and Pacific, $207 \mathrm{p}$.

12. European Commission, 2013. The impact of EU consumption on deforestation: Comprehensive analysis of the impact of EU consumption on deforestation. Technical Report - 063. Study funded by the European Commission, DG ENV, doi: 10.2779/822269. 


\section{Elena MATEI, Daniel LUCHEȘ, Gabriela MANEA, Iuliana VIJULIE, Mihaela PREDA, Octavian COCOŞ}

13. European Environment Agency, 2016. European forest ecosystems State and trends, Luxembourg: Publications Office of the European Union, doi:10.2800/964893.

14. European Landscape Convention, 2000. European Treaty Series, No. 176, 2000. http://conventions.coe.int. Accesed in November, 2020.

15. Flueck, W. T., 2009. Evolution of forest systems: the role of biogeochemical cycles in determining sustainable forestry practices. Ecology and Society, 14(2): r4. http://www.ecologyandsociety.org/vol14/iss2/resp4/. Accesed in December, 2020.

16. Food and Agriculture Organization 2001. Public Perception of Forestry Industry and Environment, Advisory Commitee on Paper and Wood Products. Shanghai, China. http://www.fao.org/forestry/12715-02bb61b57cf6eeb4eb57c45078b496970.pdf.

17. Forest Europe, 2020. State of Europe's Forests 2020, Ministerial Conference on the Protection of Forests in Europe FOREST EUROPE Liaison Unit Bratislava.

18. Griffiths, P., Kuemmerle, T., Baumann, M., Radeloff, Volker, C., Ioan V. Abrudan, I.V., Lieskovsky, J., Munteanu, C., Ostapowicz K., \& Hostert, P., 2014. Forest disturbances, forest recovery, and changes in forest types acrossthe Carpathian ecoregion from 1985 to 2010 based on Landsat image composites, Remote Sensing of Environment, Vol. 151, p. 72-88. http://dx.doi.org/10.1016/j.rse.2013.04.022.

19. Hecht, S. B., 2011. The new Amazon geographies: insurgent citizenship, "Amazon Nation" and the politics of environmentalisms, Journal of Cultural Geography, Vol. 28(1), p. 203223, https://doi.org/10.1080/08873631.2011.548500.

20. Hofstede, G., 1991. Empirical models of cultural differences. In: N. Bleichrodt \& P. J. D. Drenth (Eds.), Contemporary issues in cross-cultural psychology (p. 4-20), Swets \& Zeitlinger Publishers.

21. Knorn, J., Kuemmerl e, T., Radeloff, V. C., Szabo, A., Mindrescu, M., Keeton, W.S., Abrudan, I., Griffiths, P., Gancz, V. \& Hostert, P., 2012. Forest restitution and protected area effectiveness in post-socialist Romania, Biological Conservation, Vol. 146(1), p. 204-212.

22. Kogan, S. M., Wejnert, C., Chen, Y., Brody, G. H., \& Slater, L. M., 2011. Respondent-driven sampling with hard-to-reach emerging adults: An introduction and case study with rural African Americans. Journal of Adolescent Research, Vol. 26, p. 30-60.

23. Kuemmerle, T., Hostert, P., Radelof,f V.C., Van Der Linden, S., Perzanowski, K., Kruhlov, I., 2008. Cross border comparison of post-socialist farmland abandonment inthe Carpathians. Ecosystems Vol. 11, p.614-628.

24. Larson, A. M., Dahal, G.R., 2012. Forest tenure reform: New resource rights for forest-based communities? Conservation and Society, Vol. 10, p. 77-90.

25. Law no. 18.1991. Land Law\&Legea fondului funciar, Official Gazzette, no. 1/05.01.1998.

26. Law no. 46. 2008. Forestry Code, Official Gazzette, 238/27 mar. 2008.

27. Law no. 247.2005 on property and justice reform, as well as some related measures, Official Gazzette 653 , dfrom 22 July 2005.

28. Law no.1 rom 11 Januarie 2000, regarding the reconstitution of the property right over the agricultural and forest lands, requested according to the provisions of the Land Fund Law no. 18/1991 and of Law no.169/1997, Official Gazzette, 8/12 Jan. 2000.

29. Mantescu, L., \& Vasile, M. 2009. Property reforms in rural Romania and community based forests, Romanian Sociology, Vol. 7(2), p. 95-113.

30. Matei, E., Saghin, D., Manea, G., Cococs, O., Cuculici, R., Vijulie, I., \& Matei, D., 2016. Semi-subsistence farming development in a Carpathian declining mining area. A microscale study of landowners' perception: Stulpicani commune, Romania. Procedia Environmental Sciences, Vol.32, p. 352-363, Doi: 10.1016/j.proenv.2016.03.041.

31. Matei, E., Saghin, D., Dumitrache, L., Nae, M., 2018. Multidimensional Approach on Sustainability of Ageing in Romanian Residential Care Centres for Elders, Sustainability, Vol.,10, p.3336; doi:10.3390/su10093336 www.mdpi.com/journal/sustainability.

32. Mbatu, R. S., 2009. Forest exploitation in Cameroon (1884-1994): an oxymoron of top-down and bottom-up forest management policy approaches. International Journal of Environmental Studies, Vol. 66(6), p. 747-763. DOI: 10.1080/00207230902860935.

33. Meijaard, E., Abram, N.K., Wells, J.A., Pellier, A. S., Ancrenaz, M., Gaveau, D. L. A., Runting, R.K., \& Mengersen, K. 2013. People's Perceptions about the Importance of Forests on Borneo. PLoS One, Vol. 8(9): e73008, doi: 10.1371/journal.pone.0073008.

34. Munteanu, C., Kuemmerle, T., Boltizia, M., Butsic, V., Gimmi, U., Halada, L., Kaim, D., Király, G., Konkoly Gyuró, E., Kozak, J., Lieskovský, J., Mojses, M., Müllerf, D., Ostafin, K., Ostapowicz, K., Shandra, O., Štych, 
P., Walker, S., \& Radeloff, V., 2014. Forest and agricultural land change in the Carpathian region? A meta-analysis of long-term patterns and drivers of change, Land Use Policy, Vol. 27, p. 373-386.

35. Nichiforel, L., Deuffic, P., Thorsen, B. J., Weiss, G., Hujala, T., Keary, K., Lawrence, A., Avdibegović, M., Dobšinská, Z., Feliciano, D., Górriz-Mifsud, E., Hoogstra-Klein, M., Hrib, M., Jarský, V., Jodłowski,K., Lukmine, D., Pezdevšek Malovrh, Š., Nedeljković, J., Nonić, D., Krajter Ostoić, S., Pukall, K., Rondeux, J., Samara, T., Sarvašová, Z., Scriban, R. E., Šilingienė, R., Sinko, M., Stojanovska, M., Stojanovski, V., Stoyanov, T., Teder, M., Vennesland, B., Wilhelmsson, E., Wilkes-Allemann, J., Živojinović,I., \& Bouriaud, L., 2020, Two decades of forest-related legislation changes in European countries analysed from a property rights perspective, Forest Policy and Economics,Vol. 115, p. 2020.

36. NIS 2020. Tempo online. Sylviculture Data, Population Data. Accesed in December, 2020.

37. Parrotta, J., Yeo-Chang Y., \& Camacho, L. D., 2016. Traditional knowledge for sustainable forest management and provision of ecosystem services, International Journal of Biodiversity Science, Ecosystem Services \& Management, 12(1-2), p. 1-4, DOI: 10.1080/21513732.2016.1169580.

38. Pătru-Stupariu, I., Tudor, C. A., Stupariu, M. S., Buttler, A., \& Peringe, A., 2016. Landscape persistence and stakeholder perspectives: The case of Romania's Carpathians. Applied Geography, Vol. 69, p. 8798.

39. Ringov, D., \& Zollo, M., 2007. The impact of national culture on corporate social performance, Corporate Governance, Vol. 7(4), p. 476-485. https://doi.org/10.1108/14720700710820551.

40. Rousseuw, P. J., 1987. Silhouettes: a Graphical Aid to the Interpretation and Validation of Cluster Analysis. Computational and Applied Mathematics, Vol. 20, p. 53-65. doi:10.1016/03770427(87)90125.

41. Tomich, T. P., Thomas, D.E., van Noordwijk, M., 2004. Environmental services and land use change in Southeast Asia: from recognition to regulation or reward? Agriculture Ecosystems \& Environment, Vol. 104, p. 229-244.

42. Turner, W. R., Brandon, K., Brooks, T. M., Gascon, C., Gibbs, H. K., 2012. Global biodiversity Conservation and the Alleviation of Poverty. Bioscience, Vol. 62, p. 85-92. DOI: 10.1525/bio.2012.62.1.13.

43. Vasile, M., 2020. The Rise and Fall of a Timber Baron: Political Forests and Unruly Coalitions in the Carpathian Mountains of Romania, Annals of the American Association of Geographers, Vol. 110(6), p. 1952-1968, DOI: 10.1080/24694452.2020.1723399.

44. Vijulie, I., Tîrlă, L., Manea, G., Matei, E., \& Cuculici, R., 2013. Forest management in the Piatra Craiului National Park, between economic benefits and ecosystem services, Conference volume. 5th Symposium for Research in Protected Areas, 10-12 June 2013, Mittersill, Austria, p. 783-788.

45. Vijulie, I., Tîrlă, L., Manea, G., Matei, E., \& Cuculici, R., 2018. Old-growth forests of Domogled-Valea Cernei National Park (Romania), between conservation and mismanagement, Conference volume. 6th Symposium for Research in Protected Areas, 2-3 November 2017, Salzburg, Austria, p. 675-678.

46. Walker, R., \& Simmons, C., 2018. Endangered Amazon: An Indigenous Tribe Fights Back Against Hydropower Development in the Tapajós Valley. Environment: Science and Policy for Sustainable Development, Vol. 60(2), p. 4-15, DOI: 10.1080/00139157.2018.1418994.

47. Weiss, G., 2001. Mountain Forest Policy in Austria: A Historical Policy Analysis on Regulating a Natural Resource. Environment and History, Vol. 7(3), p. 335-355. Retrieved December 16, 2020, from http://www.jstor.org/stable/20723188.

48. Wood. E. J., 2006.The Ethical Challenges of Field Research in Conflict Zones. Qualitative Sociology, Vol. 29(3), p. 373-386.

49. World Bank, 2006. Strengthening Forest Law Enforcement and Governance Addressing a Systemic Constraint to Sustainable Development. Environment and Agriculture and Rural Development Departments. Report No. 36638-GLB, The International Bank for Reconstruction and Development/The World Bank, NW Washington, DC, USA. http://documents1. worldbank.org/ curated/en/330441468161667685/pdf/366380REVISED010Forest0Law01PUBLIC1.pdf. Accesed in December, 2020.

(C) 2020 by the authors. Submitted for possible open access publication under the terms and conditions of the Creative Commons Attribution Non Commercial-No Derivatives (CC BY NC ND) 4.0 International License. (https://creativecommons.org/licenses/by-nc-nd/4.0/). 